\title{
EATING WITH INTEGRITY
}

\author{
A question of taste.
}

\section{BY DAVID BERREBY}

$\mathrm{S}$ o, how was the big dinner party? A complete disaster! Geoff and I haven't spoken since...

Not since Friday?

That's right. You know, sometimes we joke about divorce when we're arguing, but this time ... it doesn't feel safe to kid about that. It's just so silent and grim. I think he thinks I've ruined his career.

Look, I'm sure you did your best. It was a lot of pressure. All three of his new colleagues, plus the Big Boss. I'm sure you did everything right.

I thought I had. I checked everyone for allergies. Religious covenants. Lipid and corticosterone metabolism. Medications, immunizations ...

Well, you can't be too careful.

And I social-vetted the menu: everyone checked off everything. And there was nothing to offend anyone. Tempeh-salmon, made by our own 'bot, right here. All ingredients grown sterile, no contact with organic matter or pollutants...

You don't have to tell me. I know how careful we have to be. How careful you are. No one's been sick from your place in years, and how many of us can say that?

Thanks. I appreciate that, especially after what's happened. God, I don't even want to tell. It's just so mortifying.

I think you'd better, though.

Sigh. Well, then, from the top. The table is set and the containers are all sealed and ready to be opened, the dining tents are over the chairs...

You used the good ones?

Of course! Pressurized, sterilized, totally safe, near-transparent. The ones we got for our tenth anniversary. So there I am, all ready and Geoff is wandering around resterilizing forks because everything's perfect and he has nothing to do and then bing! In walks our first guest, who is also the Big Boss, and he's carrying several things that look like food boxes and I think, uh-oh. Then I think, well, of course, those must be gifts, maybe a floral hologram or something, because it can't be what I'm afraid it is. It just can't be!

Well, how could you expect that?

You know how this thing is spreading. But I didn't update before the dinner, so I managed to miss the day when Mr Big Boss became one of them.

We had three people at work do the same thing last week. It's like some damn cult!

"I hope it's not a problem," he says, with that hick accent, "but I've decided to Eat With Integrity." I mean, I about died. And the worst of it is, he's the first guest. Everyone else is going to think we approve of this kind of thing.

He's also Geoff's boss. You didn't have much choice.

I know, but I was just so ... appalled. And disgusted. And I had no idea what to do, because we don't have the equipment.

You mean it wasn't cooked?

Oh, no, of course it wasn't cooked. $\mathrm{Mr}$ Big isn't just a new-minted Integretist, he's

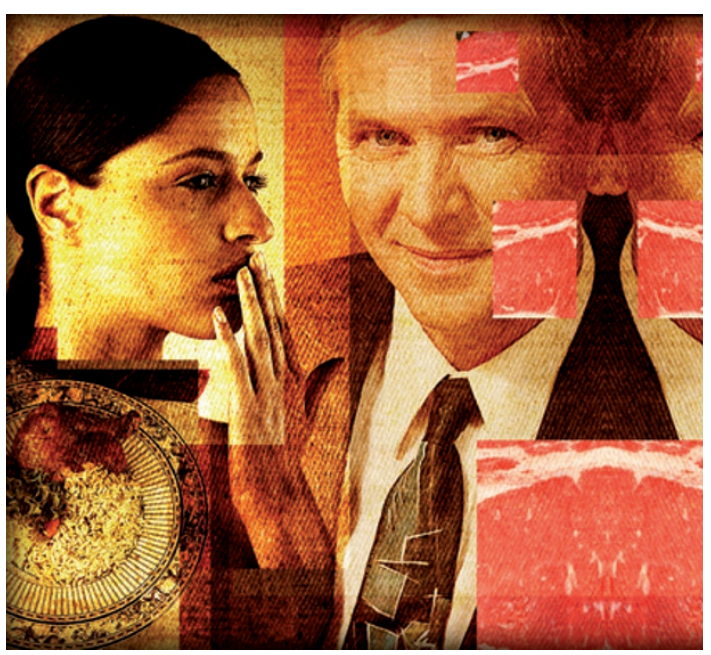

a hard-core Integretist. The meat has to be fresh as can be. He harvests himself, he cooks himself, it has to be done within the hour.

You know, I just realized, in a way it's ... well, it's sort of like what our great-grandparents ate, isn't it? Kind of like ... meat?

Exactly the problem! It's not tofurkey or FauxPorc, I can assure you. It's red and bloody and it smells of iron and something else...

I'm sorry, I think I'm going to be sick.

You asked me to tell you!

Oh, God. To think, in your own home!

Right, so there he is, and he forceps out this ... lump of flesh, this oozing ... thing like it's the Dark Ages and he looks at me cool as a cucumber and asks me if he can use the stove. And that's when most of the

$\rightarrow$ NATURE.COM

Follow Futures on

Facebook at:

go.nature.com/mtoodm others walked in. I don't know what was worse - the disgust as they looked at us, or the pity. So, of course, into this conversational vacuum leaps our newly converted Integretist. How he can talk! How he'd been thinking about Eating With Integrity for years, how much sense it made, what with all the contaminants and the epidemics, you couldn't be too careful, blah blah blah. How it was all well and good to grow your own foods and use sterile hydroponics but you couldn't be too sure, and anyway, we evolved to eat meat, and the fact that there are 10 billion of us on Earth doesn't change our basic anatomy, yak yak yak. Stem-cell technology is perfected now, and you can grow whatever you like, they have scaffolds for anything, muscle, liver, sweetbreads ...

Oh, my. No one spoke up?

He's the boss! No one dared. And I think they were all just stunned to see that this movement's spreading into their own lives, into their own office. It's not just for recovering plague victims and famine survivors any more.

You know, I saw something the other night about that. The Integretists are getting up to $20 \%$ in some cities. Once it costs nothing to clone yourself, a certain kind of person thinks, well, why not?

Meanwhile the stove is doing what it can, trying to cook this ... this lump. So it starts to ... smell, you know? And a couple of the more sensitive people, Geoff's brother, for one, they excuse themselves. And that sets off our guest.

It's the safest meat there is, he says. People didn't have to agree, but they shouldn't feel free to be downright rude.

Bit of a buzz-kill, eh?

... So then people force themselves to sit down, and they're tented up, and their containers unseal, but... God, I can still see it! No one eats a thing. We're all just too disgusted and perplexed, so the only sound at the table is my one happy guest, Eating With Integrity, happily chewing away on what he keeps insisting is the only $100 \%$ safe and healthy food left: his own flesh, cloned and grown in a vat next to his coffee machine. I can still see him there, having harvested himself and cooked himself, now eating himself; holding up his fork to our averted eyes, smiling and saying, now this, this is Eating With Integrity! -

A science writer, David Berreby writes the Mind Matters blog at bigthink.com/blogs/ Mind-Matters and is the author of Us and Them: The Science of Identity. He lives in Brooklyn, New York. 